\title{
EFFECT OF ETHEPHON ON HARDENING OF Pachystroma longifolium SEEDLINGS ${ }^{1}$
}

João Alexandre Lopes Dranski ${ }^{3}$, Ubirajara Contro Malavasi², Marlene de Matos Malavasi² e Douglass Frederick Jacobs ${ }^{4}$

\begin{abstract}
Immediately after planting, tree seedlings face adverse environmental and biotic stresses that must be overcome to ensure survival and to yield a desirable growth. Hardening practices in the nursery may help improve seedling stress resistance through reduction of aboveground plant tissues and increased root volume and biomass. We conducted an assay to quantify changes in the morphogenesis following application of ethephon on seedlings of Pachystroma longifolium (Ness) I. M. Johnst.during hardening. The results showed no effect of the ethephon treatments on the number of leaves but a reduction of up to $50 \%$ in seedling height increment, and an increase in stem diameter increment of up to $44 \%$ with the $600 \mathrm{mg} \mathrm{L}^{-1}$ ethephon treatment, which consequently altered seedling Dickson Quality Index. Our results indicate that ethephon may help to promote desired morphological changes that occur during seedling hardening in nurseries.
\end{abstract}

Keywords: Seedling morphogenesis; Growth regulators; Ethylene.

\section{EFEITO DO ETEFON NA RUSTIFICAÇÃO DE MUDAS DE Pachystroma longifolium}

\begin{abstract}
RESUMO - Imediatamente após o plantio, mudas florestais devem superar os diversos estresses bióticos e ambientais para garantir sobrevivência e exibir crescimento desejável. Práticas rustificativas no viveiro podem ajudar a melhorar a resistência aos estresses por meio da redução do crescimento da parte aérea e aumento do volume e biomassa radicular. $O$ ensaio foi realizado objetivando quantificar alterações na morfogênese de mudas de Pachystroma longifolium (Ness) I. M. Johnst durante a rustificação após a aplicação de etefon. Não ocorreu efeito do etefon no número de folhas, mas houve redução de até $50 \%$ na altura das mudas e aumento no diâmetro do coleto de até $44 \%$ com o tratamento de $600 \mathrm{mg} \mathrm{L}^{-1}$ de etefon, o que, consequentemente, aumentou o Índice de Qualidade de Dickson. Os resultados indicaram que o uso de etefon promove alterações morfológicas desejáveis durante a rustificação da muda em viveiro.
\end{abstract}

Palavras-chave: Morfogênese de mudas; Reguladores de crescimento; Etileno.

\section{INTRODUCTION}

The success of establishing high productivity forest stands is related to seedling quality (CARNEIRO, 1995; CLOSE et al., 2005). After planting, seedlings face adverse environmental and biotic conditions that must be overcome to produce desirable volumetric growth (GOMES et al., 1991). Problems associated with seedling production in the nursery have been a major cause of seedling field mortality (JOHNSON, 1996; JACOBS et al., 2004; THOMAS, 2009).

Overall, container-grown seedlings are prepared for planting by exposure to drought and nutrient stresses accomplished through cessation of irrigation and fertilization at the end of the growing season; this practice

\footnotetext{
${ }^{1}$ Recebido em 19.02.2012 aceito para publicação em 24.05.2013.

${ }^{2}$ Universidade Estadual do Oeste do Paraná, UNIOESTE, Brasil. E-mail: <biramalavasi@yahoo.com.br> e $<$ marlenemalavasi@yahoo.com.br>.

${ }^{3}$ Cooperativa Central de Pesquisa Agrícola, COODETEC, Brasil. E-mail: <joaodranski@ yahoo.com.br>.

${ }^{4}$ PurdueUniversity, Estados Unidos da América do Norte. E-mail: <djacobs@ purdue.edu>.
} 
reduces growth but increases hardiness (CARNEIRO, 1995; TELEWSKI; PRUYN, 1998; ROSSI et al., 2008; JACOBS; LANDIS, 2009;ZHANGetal., 2009; RAGONEZI et al., 2010). Hardening results in changes in the seedling morphology with reduction of the aerial plant tissues and increased root volume and biomass. Fast-growing tree species exhibit an exponential growth phase soon after germination, which often results in seedlings with an imbalance between above and belowground tissues under non-restrictive growth conditions. In this sense, hardening results in alteration of the exponential growth to a sigmoid pattern.

Mechanical stimuli in plants induce an increase in auxin up to production of ethylene (ERNER; JAFFE, 1982) probably through the mediation of an elicitor (TAKAHASHI; JAFFE, 1984) of the 1aminocyclopropane-1-carboxylic acid (ACC) pathway (JAEGHER et al., 1987). The effects of ethylene have been observed in practically all aspects of plant growth and development, ranging from seed germination to senescence of various organs and in many responses to environmental stress (ABELES et al., 1992; REID, $1995)$ as well as to changes in xylem increment and wood properties (ROBNETT; MOREY, 1974).

Surprisingly, there is not much information on the role of auxin and other plant growth regulators in thigmomorphogenetic plant responses. Erner and Jaffe (1982) reported the accumulation of auxin-like substances and higher levels of abscisic acid in response to mechanical bending. These authors hypothesized that the accumulation of these plant growth regulators resulted earlier from ethylene production in the thigmomorphogenetic response, and that it was responsible for the reduction in shoot elongation. However, Johnson et al. (1998) produced contrasting results to this hypothesis when they observed that ethylene mutants still respond to mechanical perturbations with a reduction in shoot elongation. Therefore, the role of plant growth regulators in the post mechanoperception-thigmomorphogenetic response is still open to investigation. Thus, we conducted an experiment to quantify changes in the morphogenesis following application of ethephon on seedlings of Pachystroma longifolium (Ness) I. M. Johnst. during hardening.

Ethylene is produced from methionine in all tissues of higher plants in a 3-step process (McKEON et al., 1995). Ethylene production varies according to the

Revista Árvore, Viçosa-MG, v.37, n.3, p.401-407, 2013 type of tissue, plant species, and stage of plant development. Ethylene synthesis occurs in the cell vacuole and its movement occurs by gas diffusion through intercellular spaces and vascular tissues. Among the many physiological effects, ethylene promotes the growth of coarse and fine roots, and it inhibits the action and the translocation of auxins in the aboveground plant tissues as well. Therefore, ethylene alters growth patterns by reducing cell elongation and increasing longitudinal cell elongation (TAIZ; ZEIGER, 2006). Ethephon (acid 2-chloroethylphosphonic) stimulates the endogenous production of ethylene without disruption of the apical meristem. Additionally, ethephon promotes the conjunction to ethylene mediated by the alkalinity of the cytoplasm (JOHNSON, 1996).

Pachystroma longifolium, popularly known as espinheira-santa, occurs throughout the semi-deciduous forest region of the sub-montane and alluvial vegetation formation in the basin of Paraná state, Brazil. The species is characterized by fast growth, occupying the high canopy forest and favoring plant succession through the establishment of undergrowth (SOUZA; VÁLIO, 2001). It is also considered a potentially important tree species for conservation of forestation and reforestation programs (HÜLLER et al., 2009).

\section{MATERIALAND METHODS}

The experiment was conducted in a shade house (50\% shading) at Universidade Estadual do Oeste do Paraná, Brazil from 2010 to 2011. The average temperature of the propagation environment was $27.0 \pm 3.0^{\circ} \mathrm{C}$ with a relative humidity of $70.0 \% \pm 9.0 \%$. The experiment was conducted as a completely randomized design with four replications of ten seedlings each. The treatments consisted of foliar spraying of acid 2-chloroethylphosphonic (Ethrel ${ }^{\odot}$ with $240 \mathrm{~g} \mathrm{~L}^{-1}$ of ethephon) in formulations of 0 (control), $150,300,450$ and $600 \mathrm{mg} \mathrm{L}^{-1}$ of water.

Pachystroma longifolium seeds were collected during the second semester of 2009 from 15 mature trees located in Missal (2502 $50^{\prime \prime}$ ' S and 54 ${ }^{\circ} 17^{\prime} 06^{\prime \prime} \mathrm{W}$ ) and Mercedes (24' 24' $25^{\prime \prime} \mathrm{S}$ and 54 $4^{\circ} 07^{\prime} 47^{\prime \prime} \mathrm{W}$ ) in state of Parana, Brazil, at an altitude of of $240 \mathrm{~m}$. Seeds were sown into plastic conical containers of $120 \mathrm{~cm}^{3}$ of volume and dimensions of $38 \mathrm{~mm} \times 140 \mathrm{~mm}$ (diameter $\times$ length) filled with a mixture of a commercial pine bark substrate $\left(\right.$ MecPlant $\left.^{\odot}\right)$ and local soil at a ratio of $4: 1(\mathrm{v} / \mathrm{v})$ with the addition of $100 \mathrm{~g}$ of controlled-release fertilizer

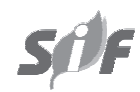


(Osmocote ${ }^{\odot} 8 \mathrm{~N}-5 \mathrm{P}-9 \mathrm{~K}$ six months release) in $50 \mathrm{~kg}$ of substrate. Plugs were arranged in plastic trays with capacity for 96 plugs, which received daily irrigation.

Thirty-two weeks after seeding, seedlings reached a height of $24.6 \pm 2.9 \mathrm{~cm}$, with a stem caliper of 3.54 $\pm 0.41 \mathrm{~mm}$, and a number of leaves of $1.2 \pm 3.8$. At this growth stage, seedlings received two spray applications of ethephon with an interval of fifteen days apart with a manual backpack sprayer $\left(\right.$ Jacto $^{\odot}$ ) working at $8.0 \mathrm{Kgf} \mathrm{cm}^{2}$ with a conical spray tip delivering $615 \mathrm{~mL} \mathrm{~min}^{-1}$ at $310 \mathrm{kPa}$. Seedlings were sprayed until dripping.

Fifteen days after the second spraying, we recorded the number of leaves, determined the increments in seedling height and stem diameter and quantified root and shoot biomass after oven drying at $65^{\circ} \mathrm{C}$ for 72 hours. Additionally, we calculated seedling quality index according to Dickson et al. (1960).

The data were tested for normality of residual distribution by the Lilliefors Test and homogeneity of the variance by the Cochran \& Bartlet Test. The data was then subjected to analysis of variance and significant differences among means were evaluated according to regression analysis using software SAEG (Fundação Artur Bernardes, Viçosa, MG, BR) at $p \leq 0.05$ of probability.

\section{RESULTS AND DISCUSSION}

After day 30, there was no significant effect $(p \geq 0.05)$ of ethephon on the number of leaves (data not shown), which averaged $19 \pm 4$ leaves per seedling over the treatments. Spray formulations above $450 \mathrm{mg} \mathrm{L}^{-1}$ caused epinasty in the leaves of the upper third of the crown, which is characteristic of ethylene toxicity (TAIZ; ZEIGER, 2006).

The results showed significant effects of ethephon treatments on growth increments with a linear adjustment $(p \leq 0.05)$ indicating a reduction of up to $50 \%$ in height increment, and an increase in stem diameter increment of up to $44 \%$ between the control $\left(0 \mathrm{mg} \mathrm{L}^{-1}\right)$ and the $600 \mathrm{mg} \mathrm{L}^{-1}$ treatment (Figure 1).

Root and shoot dry weights showed significant effects of ethephon. Application of $350 \mathrm{mg}$ of ethephon per liter of water resulted in the largest gain (45\%) of root biomass $\left(1.02 \mathrm{~g} \mathrm{seedling}^{-1}\right)$, as well as a reduction of up to $28 \%$ in shoot biomass with $600 \mathrm{mg} \mathrm{L}^{-1}$ compared to the control treatment (Figure 2).
The Dickson Quality Index (DQI) showed a significant effect of ethephon application with a quadratic polynomial fit $(p \leq 0.05)$ with maximum DQI value of

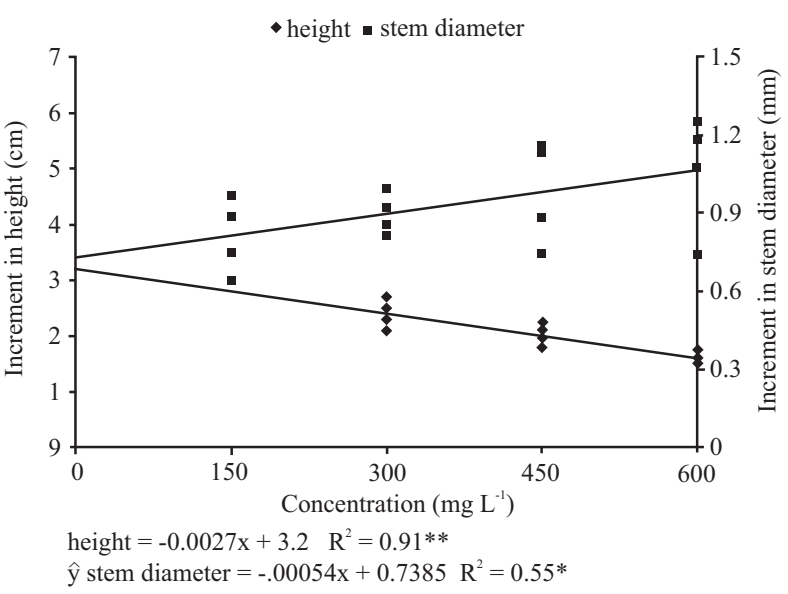

Figure 1 - Increments in height and stem diameter of Pachystroma longifolium seedlings treated with ethephon spray applications. * and ** significant at $p \leq 0.05$ or 0.01 , respectively.

Figura 1 - Incrementos na altura e no diâmetro do coleto de mudas de Pachystroma longifolium submetidas à pulverização com etefon. * $e * *$ Significativos a $p \leq 0,05$ ou 0,01 , respectivamente.

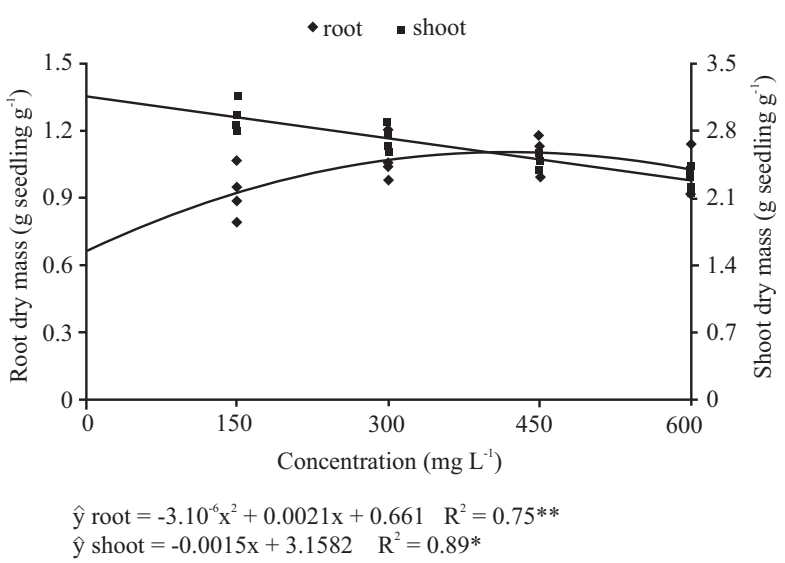

Figure 2 - Root and shoot dry mass of Pachystroma longifolium seedlings treated with ethephon spray applications. $* *$ Significant at $p \leq 0.01$.

Figura 2 - Massa seca de raízes e parte aérea de mudas de Pachystroma longifolium submetidas à pulverização com etefon. ** significativo a $p \leq 0.01$

Revista Árvore, Viçosa-MG, v.37, n.3, p.401-407, 2013 
0.57 achieved with a concentration of $450 \mathrm{mg} \mathrm{L}^{-1}$, which represents a quality increase of $58 \%$ compared to the control seedlings (Figure 3 ).

The morphological effects in this study confirm those reported by Graham and Linderman (1981), who measured an increase in root biomass and a reduction in shoot biomass of Pseudotsuga menziesii seedlings in response to six ethylene concentrations ranging from 0.006 to $0.5 \mu \mathrm{mol}$ by adding ethephon as a soil drench to the root zone. The effect of ethephon concentration is likely to be species-specific given that the same authors mentioned that formulations above $0.15 \mu \mathrm{mol}$ (equivalent to $150 \mathrm{mg} \mathrm{L}^{-1}$ ) inhibited the formation of lateral roots, which was not observed in this experiment.

Rossi et al. (2008) found that pulverization of ethephon in the aboveground tissues of Pinus taeda seedlings caused thickening of tap roots, and an increase in the number of secondary roots in the middle and lower portion of the root system. A large root system tends to have a high number of fine roots that are more efficient in absorbing and transporting water and nutrients, as well as in producing growth regulators such as cytokinin, abscisic acid and auxin (SCAGEL; LINDERMAN, 2001; MALAVASI; MALAVASI, 2006).

Carneiro (1995) stated that root dry weight can serve as a fundamental measure of photoassimilate storage in plants. Based on the reduction of above

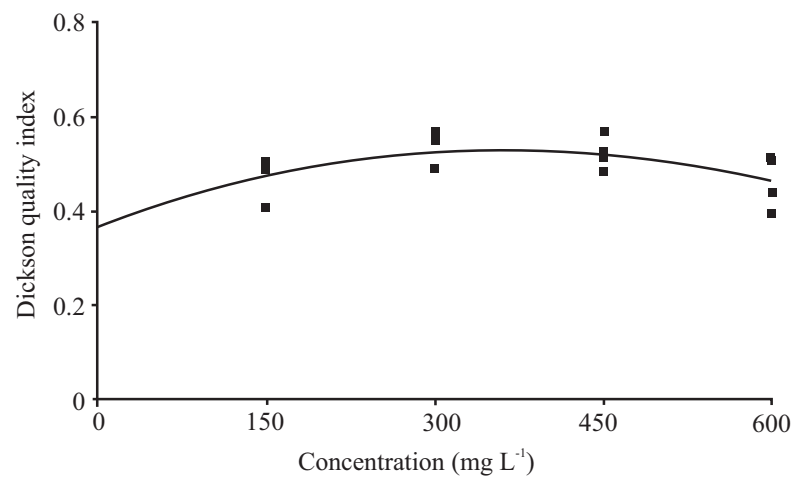

$\hat{y}$ Dickson quality index $=-10.10^{-6} \mathrm{x}^{2}+0.0009+0.3645 \mathrm{R}^{2}=0.71^{* *}$

Figure 3 - Dickson quality index of Pachystroma longifolium seedlings treated with ethephon spray applications. ** significant at $p \leq 0.01$.

Figura 3 - Índice de qualidade de Dickson de mudas de Pachystroma longifolium submetidas à pulverização com etefon. $* *$ significativo a $p \leq 0.01$.

Revista Árvore, Viçosa-MG, v.37, n.3, p.401-407, 2013 ground tissue and increase of root biomass, $P$. longifolium seedling root systems may act as a storage organ in response to ethephon application. The increments express growth rate as a function of time and reflect growth vigor (BENINCASA, 2003). An increase of ethephon spray formulation reduced overall stem growth and increased cell elongation of the aboveground plant tissues. These morphological changes are expected during seedling hardening according to Jacobs and Landis (2009). Del Campo et al. (2010) reported that field survival of Quercus ilex seedlings was positively correlated with stem diameter and negatively correlated with plant height.

The results achieved by spraying ethephon on seedlings of Pachystroma longifolium can be attributed either to the inhibition of auxin in the apical meristem in response to an increased synthesis of oxidative enzymes (such as peroxidases, and IAAoxidase) in the aboveground plant tissues, or to stem caliper growth in response to the exogenous ethylene (JOHNSON, 1996; PEREIRAet al., 2004; TAIZ; ZEIGER, 2006). Medri et al. (1998) found that exogenous application of ethylene or stimulation of the biosynthesis by flooding in Peltophorum dubium seedlings resulted in stem caliper growth due to cellular hyperplasia and hypertrophy. Additionally, the formation of aerenchyma, which is directly linked to an increase on phellogen activity, was also promoted by ethylene.

Our results for aboveground seedling increments are parallel to those of Björklund (2007), who reported that ethylene alters the alignment of microtubules and cellulose microfibrils of primary cell walls that in turn induces modification of their orientation from transverse to longitudinal. As a consequence, ethylene promotes turgor pressure in the longitudinal direction, resulting in radial growth rather than elongation.

In a study with Abies balsamea seedlings submitted to apical bud pruning and application of lanolin paste with formulations of ethephon, Eklund and Little (1998) reported that the increase in stem caliper growth was related either to accumulation of IAA in cambium cells or to biochemical modifications such as the increase of carbohydrates fructose, glucose and sucrose in the vascular bundles. According to Pereira et al. (2004), ethylene has a synergistic effect in the presence of auxin and cytokinin on the xylogenesis,

Revista Árvore, Viçosa-MG, v.37, n.3, p.401-407, 2013 
which controls lignifications by mediating the activity of peroxidase in cell walls. Consequently, ethylene action would be linked to the regulation of phenylalanine ammonia-lyase (PAL) and peroxidase in the lignification process

Based on the results of root biomass, it can be inferred that increasing concentrations of ethylene promoted synthesis of auxin in the root system of $P$. longifolium seedlings, which stimulated further root growth. This result is similar to that of Scagel and Linderman (2001), who reported that soaking roots of Pseudotsuga menziesii seedlings in a solution of $50 \mathrm{mg} \mathrm{L}^{-1}$ of ethephon for 10 minutes promoted accumulation of IAA either in the conjugated or in the free form that could be detected for up to four months after planting. The same authors also concluded that ethephon treatment induced a reduction in seedling height, an increase in stem caliper, and growth of new roots in the nursery with a significant positive correlation with survival after planting.

This study is based on the assumption that ethylene is a protagonist for morphological changes in $P$. longifolium seedlings. Consequently, efforts to promote endogenous synthesis by other methods, and synergistic effects with other groups of plant hormones should be investigated. Additionally, field tests of survival and ability to develop new roots after planting should follow.

Our results indicate that the use of ethephon reduced aboveground growth and significantly increased the root biomass of $P$. longifolium, validating its use to promote the morphological changes expected during seedling hardening in nurseries. In this case, the concentration of $350 \mathrm{mg}$ of ethephon per liter of water provided adequate shoot:root balance under these experimental conditions.

\section{ACKNOWLEDGEMENTS}

The authors thank CNPq (Brazilian National Research Council) and CAPES (Brazilian Federal Agency for the Support and Evaluation of Graduate Education).

\section{REFERENCES}

ABELES, F. B.; MORGAN, P. W., SALTVEIT JR, M.E. Ethylene in plant biology. 2.ed edn., San Diego, USA: Academic Press, 1992. 414 p.
BENINCASA, M. M. P. Análise de crescimento de plantas (noções básicas). 2 ed. Jaboticabal, SP: FUNEP, 2003. 41 p.

BJÖRKLUND, S. Plant hormones in wood formation, novel insights into the roles of ethylene and gibberellins. 2007. 53f. Thesis (Doctoral in Forest Sciences) Swedish University Swedish of Agricultural Sciences, Umeå, SWE, 2007.

CARneiro, J. G. A. Produção e controle de qualidade de mudas florestais. Curitiba, PR: UFPR/ FUPEF, 1995. 451 p.

CLOSE, D. C.; BEADLE, C. L.; BROWN, P.H. The physiological basis of containerised tree seedling transplant shock, a review. Australian Forestry, v. 68, n. 2, p. 112-120, 2005.

DEL CAMPO, A. D.; NAVARRO, R. M.; CEACERO, E. C. J. Seedling quality and field performance of commercial stocklots of containerized holm oak (Quercus ilex) in Mediterranean Spain, an approach for establishing a quality standard. New Forests, v. 39, n.1, p. 19-37, 2010.

DICKSON, A.; LEAF. A. L.; HOSNER, J. F. Quality appraisal of white spruce and white pine seedling stock in nurseries. Forest

Chronicles, v. 36, n. 1, p. 10-13, 1960.

EKLUND, L. H.; LITTLE, C. H. A. Ethylene evolution, radial growth and carbohydrate concentrations in Abies balsamea shoots ringed with Ethrel. Tree Physiology, v. 18, n. 6, p. 383-391, 1998.

ERNER, Y.; JAFFE, M. J. Thigmomorphogenesis, the involvement of auxin and abscisic acid in growth retardation due to mechanical perturbation. Plant Cell Physiology, v. 23, n. 6, p. 935-941, 1982.

GOMES, J.M.; et al. Efeitos de diferentes substratos na produção de mudas de Eucalyptus grandis W.Hill ex Maiden, em Win-Strip. Revista Árvore, v. 15, n. 1, p. 35-41, 1991.

Revista Árvore, Viçosa-MG, v.37, n.3, p.401-407, 2013 
GRAHAM, J. H.; LINDERMAN, R.G. Effect of ethylene on root growth, ectomycorrhiza formation, and fusarium infection of Douglas-fir. Canadian Journal of Botany, v. 59, n. 2, p. 149-155, 1981.

HÜLLER, A.; COELHO, G. C.; LUCCHESE, O. A.; SCHIRMER, J. A comparative study of four tree species used in riparian forest restoration along Uruguay river, Brazil. Revista Árvore, v. 33, n. 2, p. 297-304, 2009.

JACOBS, D. F.; LANDIS, T. D. Hardening. In: DUMROESE, R. K.; LUNA, T.; LANDIS, T.;D. (Eds). Nursery manual for native plants, guide for tribal nurseries. Washington, USA: 2009. p. 217-239. v. 1. (Agr. Hdbk 730, Depart. Agr. For. Serv.).

JACOBS, D. F.; ROSS-DAVIS, A. L.; DAVIS, A. S. Establishment success of conservation tree plantations in relation to silvicultural practices in Indiana, USA. New Forests, v.28, n.1, p.23-36, 2004.

JAEGHER, C. D.; et al. Thigmomorphogenesis in Bryoniu dioica, early events in ethylene biosynthesis pathway. Biochemie und Physiologie der Pflanzen, v. 182, p. 49-56, 1987.

JOHNSON, F. The use of chemicals to control root growth in container stock, a literature review. Ontario, CA: 1996. 20p. (Northeast Science Technologie Rpt. Tech., n. 26)

JOHNSON, K. A. et al. Aradibopsis thaliana responses to mechanical stimulation do not require ETR1 or EIN2. Plant Physiology, v.116, n.2, p.643-649, 1998.

MALAVASI, U. C.; MALAVASI, M. M. Efeito do volume do tubete no crescimento inicial de plântulas de Cordia trichotoma (Vell.) Arrab. ex Steud e Jacaranda micranta Cham. Ciência Florestal, v. 16, n. 1, p. 11-16, 2006.

MCKEON, T. A.; FERNANDEZ-MACULET, J. C.; YANG, S. F. Biosynthesis and metabolism of ethylene, In: DAVIES, P.J. (Ed.). Plant Hormones Physiology. Dordrecht, NL: Biochemistry and Molecular Biology, Kluwer Acad., 1995. p. 118-139.

Revista Árvore, Viçosa-MG, v.37, n.3, p.401-407, 2013
MEDRI, M. E.; BIANCHINI, E.; PIMENTA, J. A.; DELGADO, M. F.; CORREA, G. T.

Aspectos morfo-anatômicos e fisiológicos de Peltophorum dubium (Spr.) Taub. submetida ao alagamento e à aplicação de etrel.

Revista Brasileira de Botânica, v. 21, n. 3, p. 261-267, 1998.

PEREIRA, R. P. W.; MONTEIRO, M.B.O.; ABREU, H.S. Os fitohormônios na formação da madeira. Floresta e Ambiente, v. 11, n. 2, p. 40-47, 2004.

RAGONEZI, C.; KLIMASZEWSKA, K.; CASTRO, M. R.; LIMA, M.; OLIVEIRA, P.; ZAVATTIERI, M. A. Adventitious rooting of conifers: influence of physical and chemical factors. Trees

Structure and Function, v. 24, n. 6, p. 975992, 2010.

REID, M. S. Ethylene in plant growth, development, and senescence. In: DAVIES, P.J. (Ed). Plant hormones, physiology, biochemistry and molecular biology. 2nd edn. Dordrecht, NL: Kluwer Acad., 2005. p. 486-508.

ROBNETT, W.E.; MOREY, P.R. Effect of ethephon on mesquite and huisache stem anatomy. Weed Science, v. 22, n. 3, p. 280-284, 1974.

ROSSI, V. L.; AMARANTE, C. V. T.; FLEIG, F. D. Crescimento e qualidade de mudas de Pinus taeda L. submetidas à poda química de raízes. Ciência Florestal, v. 18, n. 4, p. 435-442, 2008.

SCAGEL, C. F.; LINDERMAN, R. G.

Modification of root IAA concentrations, tree growth, and survival by application of plant growth regulating substances to containergrown conifers. New Forests, v. 21, n. 2, p. 159-186, 2001.

SOUZA, R.P.; VÁLIO, I.F.M. Seed size, seed germination and seedling survival of Brazilian tropical species differing in successional status. Biotropica, v. 33, n. 3 p. 447-457, 2001.

TAIZ, L.; ZEIGER, E. Plant physiology. 4th edn. Sunderland, UK: Sinauer Assoc. Inc. Publ., 2006. 848 p. 
TAKAHASHI, H.; JAFFE, M. J.

Thigmomorphogenesis, the relationship of mechanical perturbation to elicitor-like activity and ethylene production. Physiologia Plantarum, v. 61, n. 3, p. 405-411, 1984.

TELEWSKI, F. W.; PRUYN, M. L.

Thigmomorphogenesis, a dose response to flexing in Ulmus americana seedlings. Tree

Physiology, v. 18, n. 1, p. 65-68, 1998.
THOMAS, D. S. Survival and growth of drought hardened Eucalyptus pilularis Sm. seedlings and vegetative cuttings. New Forests, v. 38, n. 3, p. 245-259, 2009.

ZHANG, Z. L.; ZHU, J.H.; ZHANG, Q. Q.; CAI, Y. B. Molecular characterization of an ethephon-induced Hsp70 involved in high and low-temperature responses in Hevea brasiliensis. Plant Physiology and Biochemistry, v. 47, n. 10, p. 954-959, 2009. 
